Jurnal Keuangan dan Perbankan, Vol.20, No.2 Mei 2016, hlm. 167-175

Terakreditasi SK. No. 040/P/2014

http://jurkubank.wordpress.com

\title{
ANALYSIS OF FACTORS AFFECTING THE CAPITAL STRUCTURE AND PROFITABILITY IN INDONESIAN'S MANUFACTURING COMPANY YEAR 2009 - 2013
}

\author{
Hamidah \\ Universitas Negeri Jakarta
}

\begin{abstract}
This study is to determine the effect of variable business risk, liquidity, growth and tangibility asset directly against leverage, as well as the influence of these variables directly to the profitability and indirectly moderated by leverage variable. The population studies were all manufacturing companies listed in Indonesia Stock Exchange, during year 2009 up to 2013. The sample was determined by using purposive sampling method, with the specified criteria obtained 88 sample of companies in Indonesia. This Research used financial statements data issued by the Indonesian Stock Exchange, and used path analysis techniques to answer the hypothesis of the study by using software SPSS 20.

The result shows that business risks, companies, liquidity and asset tangibility grow significantly and have negative effect on leverage. Liquidity and companies growth don't have positive effect on profitability as well as asset tangibility and leverage, while business risk have positive effect. For the indirect effect indicates there were indirect influences on profitability were tangibility asset and liquidity. For further research, the sample can be used not only in the manufacturing sector but also other sectors.
\end{abstract}

Keywords: profitability, leverage, business risk, liquidity, growth, asset tangibility, path analysis.

\section{PENDAHULUAN}

Sumber dana perusahaan berasal dari internal dan eksternal. Pemenuhan kebutuhan dana berasal dari operasi perusahaan merupakan sumber dana internal. Sedangkan eksternal perusahaan merupakan sumber dana yang diperoleh perusahaan dari pihak luar yang mengandung beban tetap atau leverage. Besaran dana internal dan eksternal, menjadi bauran struktur modal, untuk mendapatkan struktur modal yang opti- mal, perusahaan harus mengetahui faktor - faktor yang berpengaruh terhadap struktur modal. Profitabilitas meningkat akan meningkatkan sumberdana internal, sehinga akan berpengaruh negative terhadap leverage. Resiko bisnis, merupakan resiko yang dialami perusahaan kerena operasi perusahaan itu sendiri, bukan karena hutang. Risiko bisnis berhubungan negatif dengan leverage, karena dengan risiko bisnis yang besar maka, maka penggunaan sumber dana dengan beban tetap akan semakin dihindari dan leverage akan menjadi kecil.

Korespondensi dengan Penulis:

Hamidah: Telp. +628123385327

E-mail: hamidahsan@gmail.com 
Likuiditas yang mencerminkan kemampuan perusahaan dalam melunasi hutang jangka pendek perusahaan dengan uang tunai yang dimiliki. Semakin tinggi rasio likuiditas yang dimiliki perusahaan, akan mencerminkan bahwa perusahaan mempunyai kemampuan yang baik untuk melunasi hutang. Hal ini menunjukkan adanya hubungan positif likuiditas dengan leverage. Pecking order theory, perusahaan akan mendahulukan pendanaan dari internal, baru kemudian menerbitkan hutang, sehingga jika perusahaan memiliki likuiditas tinggi, maka perusahaan akan memilih untuk menggunakan dana likuidnya untuk memenuhi kebutuhan modal. Hal ini menunjukkan likuiditas memiliki hubungan negatif dengan leverage. Jeff Madura (2009) mengungkapkan hal yang menunjukkan bahwa likuiditas perusahaan berbanding terbalik dengan profitabilitas. Menurutnya, nilai likuiditas perusahaan yang tinggi dapat meningkatkan keamanan perusahaan, namun tingkat likuiditas perusahaan yang berlebihan dapat mengurangi keuntungan perusahaan Jeff Madura Pertumbuhan perusahaan yang tinggi dengan nilai hutang yang tinggi akan meningkatkan resiko kebangkrutan perusahaan, sehingga perusahaan akan membatasi hutang untuk membatasi resiko yang dialami. Hal ini menunjukkan pertumbuhan perusahaan berhubungan negatif dengan leverage. Pertumbuhan perusahaan yang semakin besar juga akan meningkatkan profitabilitas perusahaan, karena perusahaan yang semakin besar berarti tingkat operasional perusahaan semakin meningkat dan profitabilitas yang dihasilkan pun meningkat. Semakin besar nilai aset ini dapat dijadikan jaminan untuk hutang yang dilakukan perusahaan untuk memenuhi kebutuhan modal perusahaan. Sehingga dapat dikatakan tangibility asset memiliki hubungan positif dengan leverage. Kaitan tangibility asset dengan profitabilitas dapat berhubungan positif. Hal ini dapat dijelaskan bahwa semakin banyak tangibility asset yang dimiliki, maka perusahaan dapat lebih produktif sehingga akan meningkatkan proftabilitas perusahaan.

Menurut pecking order theory, perusahaan akan menggunakan dana internal terlebih dahulu untuk memenuhi modal yang dibutuhkan, baru kemudian melakukan penerbitan hutang dan terakhir adalah penerbitan saham. Hal ini menunjukkan bahwa leverage berhubungan negatif dengan profitabilitas perusahaan. Sedangkan teori struktur modal berkaitan dengan tax deductible bahwa leverage akan menimbulkan pengehematan pajak, maka ada hubungan positif antara leverage dengan profitabilitas perusahaan.

Berdasarkan uraian di atas, maka penelitian ini berusaha untuk mengetahui faktor yang berpengaruh terhadap struktur modal perusahaan dan profitabilitas perusahaan yang terdaftar di Bursa Efek Indonesia, maka penelitian ini mengambil judul "Analisis Struktur Modal dan Profitabilitas Perusahaan Manufaktur di Indonesia Tahun 2009 - 2013".

\section{Hipotesis}

H1: Resiko Bisnis, Likuiditas, Pertumbuhan Perusahaan, Tangibility Assets berpengaruh positif terhadap Struktur Modal (Leverage)

H2: Resiko Bisnis, Likuiditas, Pertumbuhan Perusahaan, Tangibility Assets, Struktur Modal (Leverage) berpengaruh positif terhadap Profitabilitas (Return on Assets)

\section{METODE}

Variabel yang digunakan dalam penelitian ini adalah struktur modal sebagai variabel endogen, profitabilitas sebagai variable endogen, resiko bisnis, likuiditas, pertumbuhan perusahaan, dan tangibility asset dan leverage sebagai variabel eksogen. Metode penelitian yang digunakan dalam penelitian ini adalah metode penelitian kuantitatif asosiatif. 


\section{Analysis of Factors Affecting The Capital Structure and Profitability in Indonesian's Manufacturing Company...}

Populasi sampel, Populasi yang digunakan dalam penelitian ini adalah perusahaan manufaktur yang tercatat di Bursa Efek Indonesia (BEI), dalam kurun waktu penelitian tahun 2009 sampai dengan tahun 2013. Sampel penelitian diambil secara purposive sampling, dimana sampel digunakan apabila memenuhi kriteria: a)pada kurun waktu penelitian. b)Tersedia data laporan keuangan tahunan selama kurun waktu penelitian, laporan keuangan diterbitkan untuk umum dan merupakan data yang diungkapkan kepada publik. c) Perusahaan manufaktur yang diteliti masih beroperasi dan masih mencatatkan diri di Bursa Efek Indonesia pada periode waktu penelitian.d) Tahun fiskal laporan keuangan perusahaan adalah dimulai dari tanggal 1 januari dan diakhiri pada tanggal 31 Desember.

Pengumpulan Data. Data dikumpulkan dengan mencatat dan melakukan pengamatan terhadap data laporan keuangan tahunan perusahaan manufaktur yang diterbitkan di Bursa Efek Indonesia (http://www.idx.co.id/).

Variabel Endogen. Variabel yang dipengaruhi atau variabel endogen dalam penelitian ini adalah leverage dan profitabilitas perusahaan. Pengukuran variabel terikat/endogen adalah sebagai berikut:

Tabel 1. Pengukuran Variabel Endogen

\begin{tabular}{cll}
\hline \multicolumn{1}{c}{ Variabel } & Singkatan & \multicolumn{1}{c}{ Pengukuran } \\
\hline Leverage & Lev & $\begin{array}{l}\text { Total Hutang } \\
\text { Total Aktiva }\end{array}$ \\
\hline Profitabilitas & Prof & $\begin{array}{l}\text { Laba Bersih } \\
\text { Total Asset }\end{array}$ \\
\hline
\end{tabular}

Sumber: Data diolah peneliti

Pengukuran Variabel Eksogen. Risiko bisnis, likuiditas, pertumbuhan perusahaan, dan tanggibality assets merupakan variabel predictor terhadap profitabilitas dan leverage perusahaan:
Tabel 2. Pengukuran Variabel Eksogen

\begin{tabular}{|c|c|c|}
\hline Variabel & Singkatan & Pengukuran \\
\hline Resiko Bisnis & Risk & $\begin{array}{l}\text { EBIT }_{t}-\text { EBIT }_{t-1} \\
\text { Aktiva } \\
\text { Lancar/Kewajiban }\end{array}$ \\
\hline Likuiditas & Liq & Lancar \\
\hline Pertumbuhan & & Laba Kotor $_{\mathrm{t}} /$ \\
\hline Perusahaan & Growth & $\begin{array}{l}\text { Laba Kotor t-1 } \\
\text { Aktiva Tetap/ }\end{array}$ \\
\hline Tangibility Asset & Tang & Total Aktiva \\
\hline
\end{tabular}

Sumber: Data diolah peneliti

\section{Analisis Data}

Analisis data mengunakan metode analisis jalur sendiri akan menggunakan regresi berganda antara variabel endogen dengan variabel eksogen untuk menentukan signifikansi pengujian dan besar pengaruh variabel eksogen terhadap variabel endogen, berikut adalah gambar diagram jalur (Path Analysis):

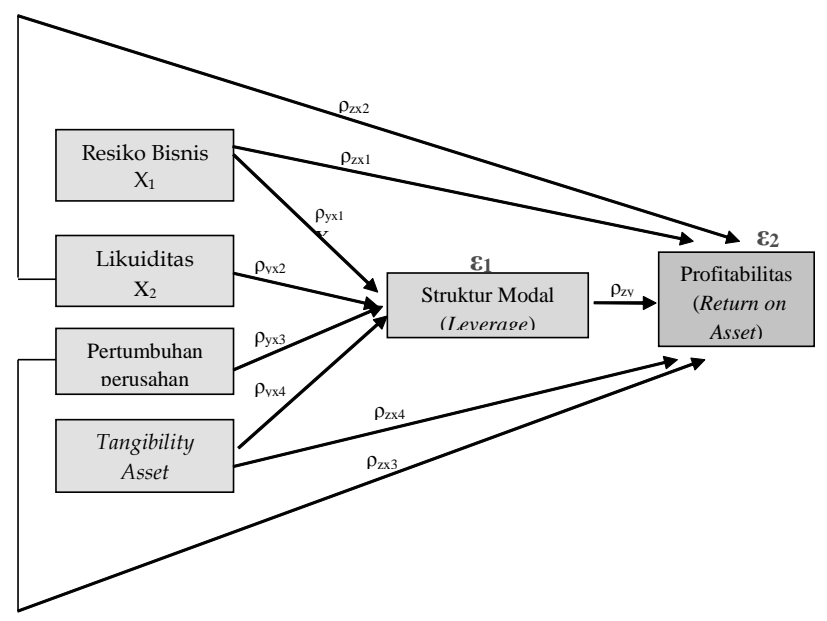

Gambar 1 Model Analisis Jalur dengan koefisien

Persamaan struktural untuk penelitian ini adalah:

Sub Struktur 1: $Y=\rho_{\mathrm{yx} 1} X_{1}+\rho_{\mathrm{yx} 2} X_{2}+\rho_{\mathrm{yx} 3} X_{2}+\rho_{\mathrm{yx} 4} X_{4}$ $\rho_{\mathrm{Y}} \varepsilon_{1}$. 
Sub Struktur 2: $Z=\rho_{z \times 1} X_{1}+\rho_{z \times 2} X_{2}+\rho_{z \times 3} X_{3}+\rho_{z \times 4} X_{4}$ $+\rho_{z y} Y+\rho_{z} \varepsilon_{2} \cdots$

\section{Hasil Analis dan Pembahasan}

Uji normalitas dilakukan dengan pengujian Kolmogorov-Smirnov menggunakan aplikasi SPSS. Hasil uji normalitas untuk sampel Indonesia. Hasil uji normalitas untuk 88 perusahaan manufaktur di Indonesia, untuk variabel leverage, profitabilitas, resiko bisnis, likuiditas, pertumbuhan perusahaan dan tangibility asset, terlihat bahwa semua data tidak berdistribusi normal. Hal ini terlihat dari nilai sig. dari masing-masing variabel tersebut berada di bawah 0.05 . Hasil pengujian di atas menggunakan tingkat kepercayaan 5\% dan menunjukkan bahwa semua variabel (leverage, profitabilitas, resiko bisnis, likuiditas, pertumbuhan perusahaan dan tangibility asset) datanya terdistribusi secara normal Hal ini tampak pada nilai sig. semua variabel berada di atas 0.05 .

Uji multikolinearitas. Hasil uji multikolinieritas menunjukkan bahwa untuk variabel leverage, resiko bisnis, likuiditas, pertumbuhan perusahaan dan tangibility asset memiliki nilai tolerance antara 0.251 sampai 0.885 untuk seluruh data observasi data perusahaan manufaktur Indonesia. Nilai tersebut lebih besar dari 0.10 sehingga dapat disimpulkan bahwa tidak terjadi multikolinearitas diantara variabel independen/eksogen. Hal ini diperkuat dengan nilai VIF untuk variabel-variabel tersebut berada pada angka 1.130 sampai dengan 3.984 yang lebih kecil dari 10.

\section{Hasil Analisis Korelasi}

Sebelum dilakukan pengujian regresi, maka akan dilakukan terlebih dahulu pengujian korelasi antar variabel. Pengujian ini untuk mengetahui apakah masing-masing variabel memiliki hubungan yang signifikan atau tidak.

Analisis jalur dilakukan untuk dua substruktur yang berbeda, yaitu untuk substruktur pertama adalah pengujian pengaruh resiko bisnis, likuditas, pertumbuhan perusahaan dan tangibility asset terhadap leverage. Substruktur kedua dilakukan untuk melakukan pengujian pengaruh leverage, resiko bisnis, likuiditas, pertumbuhan perusahaan dan tangibility asset terhadap profitabilitas yang diproksikan dengan Return on Asset (ROA).

\section{Hasil Analisis Jalur Sub Struktur Pertama}

Hasil analisis regresi untuk sampel perusahaan manufaktur Indonesia terlihat dalam tabel berikut ini:

Uji pertama yang dilakukan adalah untuk menguji pengaruh simultan dari variabel eksogen terhadap variabel endogen, yaitu pengaruh resiko

Tabel 3. Hasil Uji Koefisien Jalur Resiko Bisnis, Likuiditas, Pertumbuhan Perusahaan dan Tangibility Asset terhadap Leverage Perusahaan Manufaktur di Indonesia.

\begin{tabular}{lcrrl}
\hline \multicolumn{1}{c}{ Variabel } & Beta & t-hitung & sig. & \multicolumn{1}{c}{ Pengaruh } \\
\hline Resiko Bisnis & -0.007 & -0.083 & 0.934 & Negatif tidak signifikan \\
Likuiditas & -0.747 & -9.203 & 0.000 & Negatif signifikan \\
Pertumbuhan & & & & \\
Perusahaan & -0.109 & -1.294 & 0.199 & Negatif tidak signifikan \\
Tangibility Asset & -0.341 & -4.233 & 0.000 & Negatif signifikan \\
\hline Koefisien Nilai Kritis: & & & & \\
Determinasi (R2)=53\% & & Sig. F $=000$ & & ttabel $=1.664$ \\
F-hitung = 23.378 & & & & Ftabel $=2.49$ \\
\hline
\end{tabular}

Sumber: Data diolah oleh Peneliti 


\section{Analysis of Factors Affecting The Capital Structure and Profitability in Indonesian's Manufacturing Company...}

Hamidah

bisnis, likuiditas, pertumbuhan perusahaan dan tangibility asset terhadap leverage.

Hipotesis uji ini adalah: $\mathrm{H}_{\mathrm{a}}$ : resiko bisnis, likuiditas, pertumbuhan perusahaan dan tangibility asset berpengaruh secara simultan dan signifikan terhadap leverage

Dari analisis anova diperoleh nilai F-hitung sebesar 23.378 lebih besar dari F-tabel (2.49) dengan nilai probabilitas (sig.) adalah sebesar 0.000 . Dengan nilai F-hitung lebih besar dari F-tabel dan nilai probabilitas yang lebih kecil dari alpha (0.05), maka disimpulkan bahwa Ho ditolak dan Ha diterima, artinya terdapat pengaruh secara simultan dan signifikan antara variabel resiko bisnis, likuiditas, pertumbuhan perusahaan dan tangibility asset terhadap leverage. Nilai koefisien determinasi $\mathrm{R}^{2}$ diperoleh dari pengujian adalah sebesar 53\%, artinya kemampuan untuk menjelaskan pengaruh variabel resiko bisnis, likuiditas, pertumbuhan perusahaan dan tangibility asset terhadap leverage adalah sebesar 53\%.

Pengujian secara parsial untuk masing-masing variabel eksogen terhadap variabel endogen dapat dilihat dari perbandingan nilai t-hitung dengan $t$ tabel atau probabilitas perhitungan dari masingmasing variabel.

Hasil pengujian pengaruh resiko bisnis terhadap leverage adalah tidak signifkan dengan nilai probabilitas sebesar 0.934 lebih besar dari alpha (0.05). hal ini diperkuat dengan nilai t-hitung sebesar -0.083 lebih kecil dari t-tabel sebesar 1.664. Koefisien jalur untuk variabel resiko bisnis terhadap leverage adalah sebesar -0.007 menunjukkan bahwa resiko bisnis berpengaruh negatif tidak signifikan terhadap leverage. Karena variabel resiko bisnis berpengaruh tidak signifikan, maka akan dihapus dari model.

Hasil pengujian pengaruh likuiditas terhadap leverage dengan nilai probabilitas sebesar 0.000 lebih kecil dari nilai alpha (0.05), sehingga dapat dikatakan bahwa terdapat pengaruh yang signifikan antara likuiditas dengan leverage. Nilai koefisien jalur yang diperoleh dari analisis adalah sebesar -0.747 menunjukkan likuiditas berpengaruh negatif signifikan terhadap leverage. Hasil ini menjelaskan bahwa keberadaan likuiditas yang tinggi akan menyebabkan biaya keagenan tinggi dan kreditur akan membatasi jumlah kredit yang diberikan kepada perusahaan. Hal inilah yang menyebabkan leverage bernilai rendah.

Hasil pengujian variabel pertumbuhan perusahaan terhadap leverage adalah nilai probabilitas sebesar 0.199 lebih besar dari alpha (0.05) sehingga dapat dikatakan bahwa pengujian terdapat pengaruh tidak signifikan antara variabel pertumbuhan perusahaan terhadap leverage. Koefisien jalur yang diperoleh adalah sebesar -0.109 menunjukkan bahwa pertumbuhan perusahaan memiliki pengaruh negatif yang tidak signifikan terhadap leverage dengan kekuatan pengaruhnya sebesar 0.109. Karena variabel pertumbuhan perusahaan memberikan pengaruh yang tidak signifikan, maka variabel ini akan dihapus dari model.

Hasil pengujian pengaruh variabel tangibility asset terhadap leverage terdapat pengaruh yang signifikan (sig 0.00). Besarnya pengaruh negative

Tabel 4. Ringkasan Koefisien Jalur Perusahaan Manufaktur di Indonesia

\begin{tabular}{lccc}
\hline \multicolumn{1}{c}{ Variabel Eksogen } & Variabel Endogen & Koefisien Beta & Sig. \\
\hline Resiko Bisnis & Leverage & -0.007 & 0.934 \\
Likuiditas & Leverage & -0.747 & 0.000 \\
Pertumbuhan Perusahaan & Leverage & -0.109 & 0.199 \\
Tangibility Asset & Leverage & -0.341 & 0.000 \\
\hline
\end{tabular}

Sumber: Data Diolah Peneliti 
dengan nilai koefisien jalur sebesar -0.341, antara tangibility asset tehadap leverage.

Dari hasil ringkasan ini terlihat bahwa variabel resiko bisnis dan pertumbuhan perusahaan berpengaruh tidak signifikan terhadap leverage, sedangkan variabel likuiditas dan tangibility asset memiliki pengaruh signifikan terhadap leverage, likuiditas berpengaruh paling dominan terhadap tingkat leverage perusahaan manufaktur di Indonesia

\section{Hasil Analisis Jalur}

Analisis jalur dilakukan untuk dua substruktur yang berbeda, yaitu untuk substruktur pertama adalah pengujian pengaruh resiko bisnis, likuditas, pertumbuhan perusahaan dan tangibility asset terhadap leverage. Substruktur kedua dilakukan untuk melakukan pengujian pengaruh leverage, resiko bisnis, likuiditas, pertumbuhan perusahaan dan tangibility asset terhadap profitabilitas yang diproksikan dengan Return on Asset (ROA). Persamaan struktural untuk penelitian untuk sub struktur 2 adalah sebagai berikut: $Z=-0.361 X_{1}$ $0.231 \mathrm{X}_{4}-0.416 \mathrm{Y}+0.749$
Berdasarkan hasil pengujian dari kedua sub struktur di atas, maka akan didapatkan hasil struktur akhir dari analisis ini. Gambar struktur akhir serta koefisien jalurnya adalah sebagai berikut:

Persamaan jalur yang diperoleh adalah:

$Y=-0.625 X_{1}-0.121 X_{4}+0.787$

$Z=-0.361 X_{1}-0.231 X_{4}-0.416 Y+0.749$

\section{Uji Ketepatan Model}

Uji ketepatan model hipotesis dari data penelitan diukur dari hubungan dua koefisien determinasi $\left(\mathrm{R}^{2}\right)$ dari dua persamaan di atas. Pada persamaan pertama diperoleh koefisien determinasi $\left(\mathrm{R}^{2}\right)$ sebesar 0.381 dan koefisien determinasi $\left(\mathrm{R}^{2}\right)$ pada persamaan kedua adalah sebesar 0.439. Hasil ketepatan model adalah:

$$
\begin{aligned}
\text { R2 Model } & =1-\left(1-\mathrm{R}_{1}^{2}\right)\left(10 \mathrm{R}_{2}^{2}\right)=1-(1-0.381)(1-0.439) \\
& =1-0.347=0.653 \text { atau } 65.3 \%
\end{aligned}
$$

Hasil perhitungan ketepatan model sebesar 65.3\% menerangkan bahwa kontribusi model untuk menjelaskan hubungan kausal dari variabel

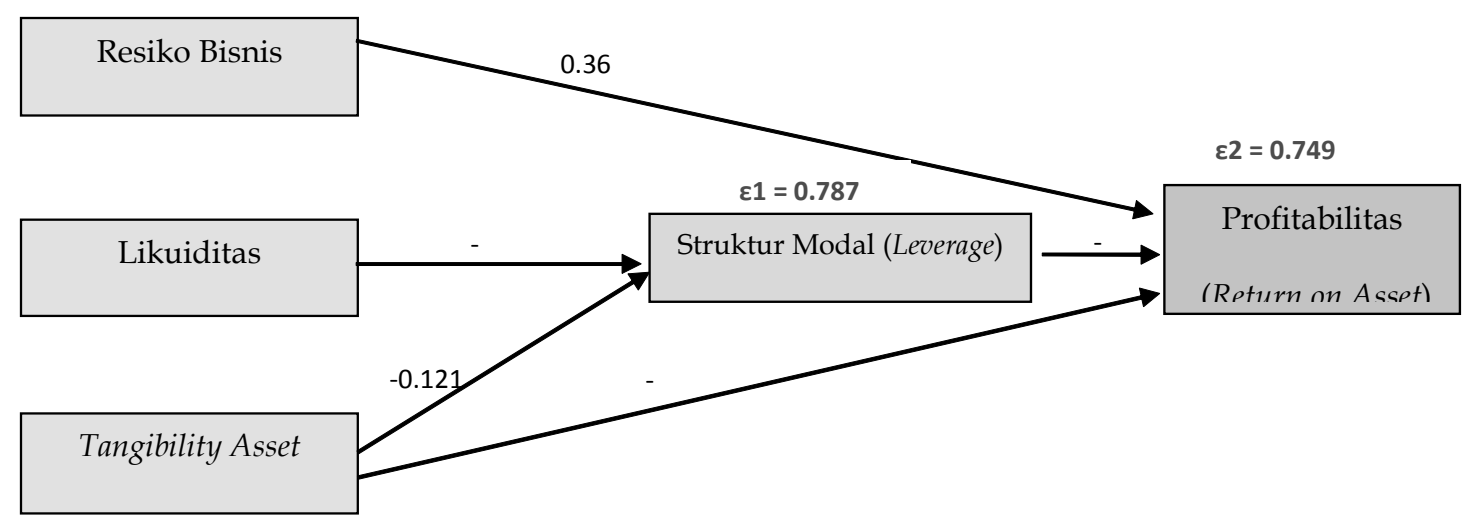

Gambar 2 Hasil Akhir Analisis Jalur Perusahaan Manufaktur di Indonesia 


\section{Analysis of Factors Affecting The Capital Structure and Profitability in Indonesian's Manufacturing Company...}

Hamidah

eksogen terhadap variabel endogen adalah sebesar $65.3 \%$ dan sisanya dijelaskan oleh variabel lain yang tidak terlibat dalam penelitian ini.

\section{Pengaruh Langsung dan Tidak Langsung Indonesia}

Gambar analisis jalur sebelumnya menjelaskan besar koesifien jalur pada setiap pengaruh dua variabel. Pengaruh antara dua variabel bisa bersifat langsung dan tidak langsung. Besarnya pengaruh langsung dihitung dari besarnya koefisien jalur yang sudah dihitung sebelumnya. Sedangkan besarnya pengaruh tidak langsung adalah jumlah hasil perkalian dari dua jalur yang menghubungkan pengaruh tidak langsung. Tabel berikut menjelaskan pengaruh langsung dan tidak langsung yang ada dalam model penelitian.

Tabel di atas menunjukkan bahwa pengaruh langsung yang paling kuat terhadap leverage adalah variabel likuiditas dengan koefisien jalur sebesar -0.625 . Pengaruh langsung terhadap profitabilitas, yang paling kuat adalah variabel leverage dengan koefisien jalur sebesar -0.416 . Sedangkan untuk pengaruh tidak langsung, likuiditas memberikan pengaruh yang paling besar yaitu sebesar 0.260. Dengan demikian, likuiditas akan memberikan profitabilitas yang lebih besar kepada perusahaan jika perusahaan juga menggunakan hutang untuk sumber pembiayaan perusahaan.

\section{KESIMPULAN}

1. Risiko bisnis memberikan pengaruh negatif tidak signifikan terhadap variabel leverage. Likuiditas berpengaruh negatif signifikan terhadap leverage perusahaan manufaktur di Indonesia. Pertumbuhan perusahaan berpengaruh negatif tidak signifikan terhadap leverage perusahaan. Tangibility asset berpengaruh negatif signifikan terhadap variabel leverage.

2. Risiko bisnis berpengaruh positif signifikan terhadap profitabilitas. Likuiditas berpengaruh positif tidak signifikan terhadap profitabilitas. Pertumbuhan perusahaan berpengaruh positif tidak signifikan terhadap variabel profitabilitas. Tangibility asset berpengaruh negatif signifikan terhadap profitabilitas. Leverage berpengaruh negatif signifikan terhadap profitabilitas. Leverage memediasi hubungan likuiditas dan tangibility asset.

3. Hasil penelitian ini mengindikasikan bahwa pengaruh likuiditas dan tangibility asset terhadap profitablitas akan lebih besar secara tidak langsung ketika melalui leverage dibandingkan

Tabel 4. Ringkasan Pengaruh Antar variabel secara Langsung, Pengaruh secara Tidak Langsung dan Pengaruh Total Perusahaan Manufaktur di Indonesia

\begin{tabular}{lccc}
\hline \multicolumn{1}{c}{ Pengaruh Antar Variabel } & $\begin{array}{c}\text { Pengaruh } \\
\text { Langsung }\end{array}$ & $\begin{array}{c}\text { Pengaruh Tidak Langsung } \\
\text { melalui Leverage }\end{array}$ & $\begin{array}{c}\text { Pengaruh } \\
\text { Total }\end{array}$ \\
\hline Resiko Bisnis $\rightarrow$ Profitabilitas & 0.361 & & 0.361 \\
Likuiditas $\rightarrow$ Leverage & -0.625 & & -0.625 \\
Leverage $\rightarrow$ Profitabilitas & -0.416 & & -0.625 \\
Tangibility Asset $\rightarrow$ Leverage & -0.121 & & -0.121 \\
Tangibility Asset $\rightarrow$ Profitabilitas & -0.231 & $(-0.121) \times(-0.416)=0.050$ & -0.181 \\
Likuiditas $\rightarrow$ Profitabilitas & 0 & $(-0.625) \times(-0.416)=0.260$ & 0.26 \\
Sumber: Data Diolah Peneliti & & &
\end{tabular}




\section{Jurnal Keuangan dan Perbankan | KEUANGAN}

Vol. 20, No.2, Mei 2016: 167-175

secara langsung tanpa melalui leverage,ini bermakna likuiditas dan tangibility asset berpengaruh terlebih dahulu pada leverage, kemudian leverage akan memberikan pengaruh yang lebih besar terhadap profitabilitas dibandingkan pengaruh langsung likuiditas dan tangibility asset terhadap profitabilitas.

\section{DAFTAR PUSTAKA}

Abbas, Ali, et al. "Determinants of Firm's Financial Performance: An Empirical Study on Textile Sector of Pakistan." Business and Economic Research, Vol. 3 No. 2: 2013.

Al Najjar, Basil dan Taylor, Peter. "The Relationship between Capital Structure and Ownership Structure: New Evidence from Jordanian Panel Data." Journal Financial Managerial Vol. 24: 2008.

Alkhatib, Khalid. "The Determinant of Leeverage of Listed Companies." International Journal of Business and Social Science, Vol. 3 No. 24: 2012.

Almajali, Yassin Amal, et al. "Factors Affecting the Financial Performance of Jordanian Insurance Companies Listed at Amman Stock Exchange." Journal of Management Research, Vol. 4, No. 2: 2012.

Amidu, Mohammed. "Determinant of Capital Structure of Banks in Ghana: an Empirical Approach." Baltic Journal of Management, Vol. 2: 2007.

Anonim. "Industri Tergantung Bahan Baku Impor." http://www.kemenperin.go.id/artikel/1835/ Industri-Tergantung-Bahan-Baku-Impor (diakses 14 November 2014).

Azis, M. A. "Pengaruh Earning Per Share (EPS) dan Pertumbuhan Penjualan terhadap Harga Saham pada Perusahaan Makanan dan Minuman yang Terdaftar di Bursa Efek Jakarta." Skripsi. Universitas Negeri Semarang: 2005.

Brigham dan Houston.Dasar - Dasar Manajemen Keuangan, Essential of Financial Management Buku 1. Jakarta: Salemba Empat, 2011.

Brigham dan Houston. Dasar - Dasar Manajemen Keuangan, Essential of Financial Management Buku 2. Jakarta: Salemba Empat, 2011.
Chechet, Ishaya Luka et al. "Determinants of Capital Structure in the Nigerian Chemical and Paints Sector." International Journal of Humanities and Social Science, Vol. 3 No. 15: August 2013.

Doðan, Mesut. "Does Firm Size Affect The Firm Profitability? Evidence from Turkey." Research Journal of Finance and Accounting, Vol.4, No.4: 2013.

Eldomiaty, Tarek. "Determinant of Corporate Capital Structure: Evidence from an Emerging Economy." International Journal of Commerce and Management Vol. 17 No. 1/2: 2007.

Haron, Razali. "Capital Structure Inconclusiveness: Evidence from Malaysia, Thailand, and Singapore." International Journal of Management Finance, Vol. 10 No. 1: 2014.

Journal UII. http://journal.uii.ac.id/index.php/Sinergi/ article/view/873 (diakses 29 Maret 2014).

Karadeniz, Erdinc, et al. "Determinant of Capital Structure: Evidence from Turkish Lodging Companies." International Journal of Contemporary Hospitality Management, Vol. 21: 2008.

Kashmir. Analisis Laporan Keuangan. Jakarta: PT. Rajagrafindo Persada, 2013.

Khalifa, Khalifa Mohamed dan Shafii, Zurina. "Factors Affecting the Financial Performance of Non-oil Industrial Companies Listed on Libyan Stock Market (LSM)." 4th International Conference on Business and Economic Research (4th ICEBR 2013) Proceeding 04 - 05: March 2013.

Kompasiana. http://m.kompasiana.com/post/read/ 555644/3/pengertian-modal.html (diakses 16 November 2014).

Leon, S.A. Jude. "The impact of Capital Structure on Financial Performance of the listed manufacturing firms in Sri Lanka." Global Journal of Commerce and Management Perspective, Vol. 2(5):56-62: 2013.

Liang, Jian. Li, Fang Liu. Song, Han-Suck. “An Explanation of Capital Structure of China;s Listed Property Firms." International Journal of Management Finance, Vol. 10 No. 1: 2014.

Lisengiya A. "Factor Influencing Companies's Leverage: Evidence from Sri Lankan Panel Data." Academicia Vol.2 Issue 3: March 2012. 


\section{Analysis of Factors Affecting The Capital Structure and Profitability in Indonesian's Manufacturing Company...}

Mas'ud H. Muchlis et al. “Risk, Corporate Strategy, Capital Structure and financial Performance: Empirical Evidence of Bank Listed in Indonesia Stock Exchange." International Journal of Business and Management Invention www.ijbmi.org Volume 2 Issue 5: May 2013.

Mehari, Daniel. Aemiro, Tilahun. "Firm Specific Factors that Determine Insurance Companies' Performance in Ethiopia." European Scientific Journal April 2013 edition vol.9, No.10: 2013.

Mirza, Ali Sidra. Javed, Attiya. "Determinants of Financial Performance of a Firm: Case of Pakistani Stock Market." Journal of Economic and International Finance, Vol. 5 (2): 2013.

Muritala, Adewale Taiwo. "An Empirical Analysis of Capital Structure on Firms' Performance in Nigeria." International Journal of Advances in Management and Economics, Vol 1. issue 5: 2012.

Nachrowi. Usman, Hardius. Pendekatan Populer dan Praktis Ekonometrika Untuk Analisis Ekonomi dan keuangan. Jakarta:Lembaga Penerbit Fakultas Ekonomi Universitas Indonesia, 2006.

Novita, Asri Bunga dan Sofie. "Pengaruh Struktur Modal dan Likuiditas terhadap Profitabilitas", e-Journal Akuntansi Trisakti Vol. 2 No. 1, 2015.

Pal, Shrabanti. "A Study on Capital Structure Determinants of Indian Steel Companies." International Journal of Business Management \& Research, Vol. 4. Issue 4: August 2014.

Pustaka Skripsi. http://www.pustakaskripsi.com/ download.php?file=2493 (diakses 31 Maret 2014).

Quang, Do Xuan. Xin, Zhong Wu. “The Impact of Ownership Structure and Capital Structure on Financial Performance of Vietnamese Firms." International Business Research Vol. 7 No. 2: 2014.
Rahadyan, Jhovy Muhammad. Perekonomian Indonesia Tergantung Situasi Politik. Jakarta: tabloid Inspirasi Vol. 3 No. 41. 2013.

Ramjee, Anil. Gwatidzo, Tendai. "Dynamic in Capital Structure Determinants in South Africa." Meditary Accountancy Research Vol. 20 No.1: 2012.

Sambasivam, Yuvaraj. Ayele, Gashaw Abate. "Study on the Performance of Insurance Companies in Ethiopia." International Journal of Marketing, Financial Services \& Management Research Vol.2 No. 7: July 2013.

Sarnowo, Jonathan. "Teori Analisis Jalur/Path Analysis." http://www.jonathansarwono.info/aj/ analisis_jalur.htm (diakses 19 November 2014).

Sunarto. Budi, Agus Prasetyo. "Pengaruh Leverage, Ukuran dan Pertumbuhan Perusahaan terhadap Profitabilitas." TEMA Vol 6 Edisi 1: Maret 2009.

Tim Progam Pascasarjana. Buku Pedoman Penulisan Tesis dan Disertasi. Jakarta: Program Pascasarjana, 2012.

UPN Jatim. http://eprints.upnjatim.ac.id/4060/1/ file1.pdf (diakses 31 Maret 2014).

Utami, Siti Rahmi. "Determinants of Capital Structure of Firms in the Manufacturing Sector of Firms in Indonesia." Netherlands: Maastricht School of Management, 2012.

Yohana, Denny dan Warnida. " Pengaruh Konsentrasi Kepemilikan, Klasifikasi Industri, Pertumbuhan Dan Risiko Terhadap Leverage Perusahaan Publik Di Indonesia", Yogyakarta: Universitas Gadjah Mada. 2005. 